\title{
Microstructural Evaluation and Mechanical Properties of an Al-Zn-Mg-Cu-Alloy after Addition of Nickel under RRA Conditions
}

\author{
Haider T. Naeem ${ }^{1,2 *}$, Kahtan S. Mohammed ${ }^{1}$ \\ ${ }^{1}$ School of Materials Engineering, University Malaysia Perils, Taman Muhibbah, Perlis, Malaysia; ${ }^{2}$ College of Engineering, Al- \\ Muthana University, Al-Muthana, Iraq. \\ Email: "haider_neem@yahoo.com
}

Received September $22^{\text {nd }}, 2013$; revised October $21^{\text {st }}, 2013$; accepted November $2^{\text {nd }}, 2013$

Copyright (C) 2013 Haider T. Naeem, Kahtan S. Mohammed. This is an open access article distributed under the Creative Commons Attribution License, which permits unrestricted use, distribution, and reproduction in any medium, provided the original work is properly cited.

\begin{abstract}
The effects of nickel in improving the mechanical properties and microstructure of $\mathrm{Al}-\mathrm{Zn}-\mathrm{Mg}-\mathrm{Cu}$ alloys produced by semi-direct chill casting were investigated. Aluminium alloys were homogenized at different temperatures conditions, which aged at $120^{\circ} \mathrm{C}$ for $24 \mathrm{~h}$ (T6 temper), and retrogressed at $180^{\circ} \mathrm{C}$ for $30 \mathrm{~min}$ and then re-aged at $120^{\circ} \mathrm{C}$ for $24 \mathrm{~h}$ (RRA). The results of the microstructural analyses showed that with adding nickel to aluminium alloy, nickel-rich dispersoid particles were formed, such as $\mathrm{Al}_{7} \mathrm{Cu}_{4} \mathrm{Ni}, \mathrm{Al}_{4} \mathrm{Ni}_{3}, \mathrm{Al}_{75} \mathrm{Ni}_{10} \mathrm{Fe}_{15}, \mathrm{Al}_{3} \mathrm{Ni}_{2}$, and $\mathrm{Al}_{50} \mathrm{Mg}_{48} \mathrm{Ni}_{7}$. Intermetallics compounds within the matrix alloy led to dispersion and fine-grain mechanisms which prevent the recrystallization and grain growth. Enhancement of mechanical properties of the alloys study is obtained through the precipitation hardening of alloying elements of the base alloy besides Ni-bearing dispersoid particles. The microstructure of these alloys was examined through optical and scanning electron microscopy along with energy dispersive X-ray and X-ray diffraction.
\end{abstract}

Keywords: Al-Zn-Mg-Cu Alloys; Intermetallic; Microstructure; Mechanical; Orowan Mechanism

\section{Introduction}

In the past several decades, a considerable commercial interest had been shown in the development of highstrength $\mathrm{Al}-\mathrm{Zn}-\mathrm{Mg}-\mathrm{Cu}$ aluminium alloys. It is aiming at a superior combination of high specific strength, high tensile strength and satisfactory corrosion resistance that renders them suitable for use in aircraft structures through heat treatments [1]. Retrogression and re-aging (RRA) is considered one of the most important heat treatments to produce aluminium-Zinc-MagnesiumCopper alloys which have higher mechanical strength and stress corrosion resistance than alloys produced under aging at T6 temper [2]. Many attempts including a chemical composition modification for $\mathrm{Al}-\mathrm{Zn}-\mathrm{Mg}-\mathrm{Cu}$ alloys and employing new heat treatments were made to further increase the properties of these alloys. Typically, the eutectic structures of aluminium-zinc-magnesiumcopper alloys consist of $\alpha-\mathrm{Al}$ and $\mathrm{MgZn}_{2}$. Several phases

${ }^{*}$ Corresponding author. such as $\mathrm{S}-\mathrm{Al}_{2} \mathrm{CuMg}, \mathrm{T}-\mathrm{Al}_{2} \mathrm{Mg}_{3} \mathrm{Zn}_{3}$, and $\mathrm{Al}_{2} \mathrm{Cu}$ are created during solidification process aluminum alloys (Al-Zn$\mathrm{Mg}-\mathrm{Cu})[3,4]$. The zinc-magnesium ratio significantly affects the formation of the $\mathrm{MgZn}_{2}$ phase. Whereas high zinc-magnesium ratio leads to building up other $\mathrm{MgZn}_{2}$ compounds that strengthen the alloys through heat treatments. Researchers continue to improve a chemical composition of Al-Zn-Mg-Cu alloys by transition elements such as zirconium ( $\mathrm{Zr})$, titanium (Ti), boron (B), Lithium (Li) and scandium $(\mathrm{Sc})$ which have been used in Al-Zn$\mathrm{Mg}-\mathrm{Cu}$ alloys; Ti coupled with B provides the finest microstructure properties for these alloys [5,6]. Prior studies have indicated the effect of nickel on the microstructure and mechanical properties of aluminium alloys. Compton et al. [7] found that adding nickel into pure aluminium forms $\mathrm{Al}_{3} \mathrm{Ni}$ through the eutectic reaction and increases alloy hardness. Yang [8] and Boyuk [9] claimed that blending nickel into aluminium-silicon alloys forms $\mathrm{Al}_{3} \mathrm{Ni}$ in addition to the $\mathrm{Al}_{7} \mathrm{Cu}_{4} \mathrm{Ni}$ and $\mathrm{Al}_{9} \mathrm{FeNi}$ phases during solidification. For aluminium-silicon-nickel al- 
loys, a nickel-rich dispersed phase insoluble at high temperature improves mechanical properties for applications in high temperatures [10-12]. Moreover, influence addition of nickel on the mechanical properties of Al-Zn$\mathrm{Mg}-\mathrm{Cu}$ alloys was investigated using numerous techniques such as; Ingot metallurgy (IM) and rapid solidification (RS). Shen [13] found that increase hardness in $\mathrm{Al}-\mathrm{Zn}-\mathrm{Mg}-\mathrm{Cu}$ alloys contained nickel produced by rapid solidification after the aging treatments. However, insufficient detail about the effect of nickel additives on microstructural and mechanical properties of $\mathrm{Al}-\mathrm{Zn}-\mathrm{Mg}-\mathrm{Cu}$ alloys. The purpose of study was to determine to affect nickel on microstructural evolution and mechanical properties of $\mathrm{Al}-\mathrm{Zn}-\mathrm{Mg}-\mathrm{Cu}$ alloy produced by chill casting, besides investigating the effects of aging and retrogresssion and re-aging treatments on them.

\section{Experimental Procedures}

\subsection{Research Material}

The present study was carried out on $\mathrm{Al}-\mathrm{Zn}-\mathrm{Mg}-\mathrm{Cu}$ aluminium alloys slabs provided by ALCAN GLOBAL AEROSPACE. The slabs were $13 \mathrm{~mm}$ thick and $20 \mathrm{~mm}$ wide. Nickel of $99 \%$ purity as additives was provided by Merck KGaA. The nominal compositions of the studied alloys are listed in Table 1. The terms "Base alloy" and "Alloy I" refer to as received alloy and alloy with $0.5 \mathrm{wt}$ \% Ni respectively. The chemical composition analysis was carried out using the arc-spark spectrometer.

Alloys were re-melted in a graphite crucible at $850^{\circ} \mathrm{C}$ $(1123 \mathrm{~K})$ in electrical resistance furnace (with accuracy of $\pm 5^{\circ} \mathrm{C}$ ). The samples were produced by a semi-direct chilling (DC) casting process proceeded in iron steel mold of $(1501 \times 30 \mathrm{w} \times 20 \mathrm{~h})$. The mold was preheated to $250^{\circ} \mathrm{C}$ prior to casting process. The casting speed about $150 \mathrm{~mm} / \mathrm{min}$, water flow rate was about $45 \mathrm{l} / \mathrm{min}$ and cooling rate of $-280^{\circ} \mathrm{C} / \mathrm{sec}$. The alloys were inverted

Table 1. The chemical composition of studied alloys (in wt. \%).

\begin{tabular}{ccc}
\hline No. & Base alloy & Alloy I \\
\hline $\mathrm{Si}$ & 0.078 & 0.114 \\
$\mathrm{Fe}$ & 0.234 & 0.265 \\
$\mathrm{Cu}$ & 1.774 & 1.543 \\
$\mathrm{Mn}$ & 0.044 & 0.043 \\
$\mathrm{Mg}$ & 2.886 & 2.665 \\
$\mathrm{Cr}$ & 0.187 & 0.188 \\
$\mathrm{Ni}$ & - & 0.557 \\
$\mathrm{Zn}$ & 6.676 & 7.076 \\
$\mathrm{Ti}$ & 0.027 & 0.053 \\
$\mathrm{Al}$ & Bal. & Bal. \\
\hline
\end{tabular}

and remelted three times to ensure complete mixing. After the casting; homogenizing treatments conducted for alloys according to $[14,15]$ within step No.1 in Table 2, followed by quenching in cold water immediately after each step of the homogenizing treatments. Thereafter ageing at T6 temper then the retrogression and re-aging (RRA) process their detailed in Table 2; quenching in cold water come after each treat.

\subsection{Microstructures Characterizations}

The microstructures were analyzed by the optical microscopy (OM) using Olympus PMG3 optical microscope. The specimens were extracted from position of $1 / 2$ height of the ingot, ground and polished according to ASTM E3-01. They were etched with Keller's reagent. The calculation of the average grain size and its analysis were carried out using the linear intercept method. In order to investigate effects of additives on the microstructure scanning electron microscopy (SEM) coupled energy dispersive X-ray (EDX) and X-ray diffraction analysis (XRD) were used.

\subsection{Mechanical Testing}

The Hv microhardness measurements were carried out on the specimens according to ASTM E92-82, "Mitutoyo DX256 series". Indentation force was set to $30 \mathrm{~N}$ and 10 sec. dwelled time. To ensure cleanliness the surfaces of the samples were polished prior to $\mathrm{Hv}$ measurement. Each reading was an average of at least ten separate measurements taken randomly on the surface of the specimens. The highest and the lowest values of the ten reading were disregarded. The tensile test was carried out at ambient temperature on plate tensile specimens using INSTRON testing machine at a ram speed of $10 \mathrm{~mm} / \mathrm{min}$. and a load of $500 \mathrm{kN}$. The tensile test specimens were prepared according to ASTM B557M-02.

\section{Results}

Figure 1 shows the optical micrographs of as-quenched alloy I sample. This sample contained incipient dendrites of aluminium-rich solid solution and an interdendritic network of intermetallic compounds around the primary

Table 2. The homogenizing and heat treatment steps for alloys studied.

\begin{tabular}{cll}
\hline No. & Type & Description of treatment \\
\hline 1 & Homogenizing & $\begin{array}{l}450^{\circ} \mathrm{C} \text { for } 2 \mathrm{~h}+470^{\circ} \mathrm{C} \text { for } 24 \mathrm{~h} \\
+480^{\circ} \mathrm{C} \text { for } 1 / 2 \mathrm{~h}\end{array}$ \\
2 & Ageing (T6) & $120^{\circ} \mathrm{C}$ for $24 \mathrm{~h}$ \\
3 & $\begin{array}{l}\text { Retrogression and reaging } \\
(\text { RRA) }\end{array}$ & $\begin{array}{l}120^{\circ} \mathrm{C} \text { for } 24 \mathrm{~h}+180^{\circ} \mathrm{C} \text { for } 1 / 2 \\
\mathrm{~h}+120^{\circ} \mathrm{C} \text { for } 24 \mathrm{~h}\end{array}$ \\
\hline
\end{tabular}




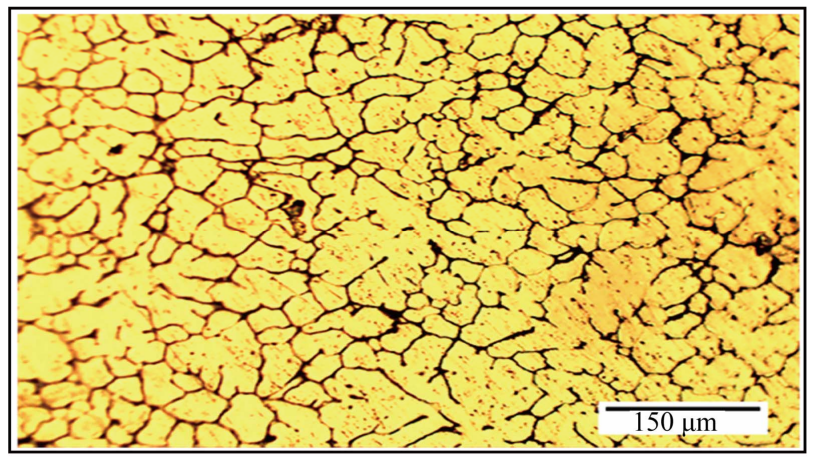

Figure 1. Optical microstructures of as-quenched alloy I sample.

grains. Several fine equiaxed grains contained columnar grains between them. Semi-direct chill casting forms fine equiaxed grain structures all over the cross sections with an average grain size of about $39 \mu \mathrm{m}$ for the alloy I sample (Figure 1). In our previously study [16] that the average grain size of about $47 \mu \mathrm{m}$ for the quenched sample of the $\mathrm{Al}-\mathrm{Zn}-\mathrm{Mg}-\mathrm{Cu}$ alloy produced by the same casting condition. Ying et al. [17] observed a grain size about $121 \mu \mathrm{m}$ for as-cast AA 7050 aluminium alloy. The grain size of as-quenched alloy I was refined by adding nickel to aluminium alloy. Nickel acted as a nucleation agent on the grains, inhibiting columnar evolution, which usually starts from the mold wall and forms appropriate sites for the nucleation of the first aluminium phases during solidification [15]. Figures 2(a) and (b) show the optical micrographs of the alloy I samples after promotive homogenizing then aging treatment at T6 temper and RRA process. The volume fraction of the dendritic network structure was gradually reduced, and the residual phases became small and sparse because of the heat treatments. The grain size of the alloy I samples (Figures 2(a) and (b)) were significantly reduced after the T6 temper and RRA process due to the interaction between alloying elements of the base alloy and nickel additives which had higher density than of them. Thus the additives of nickel formed the nucleation sites and increase the solidification rate. Besides, the additions created dispersion compounds through eutectic reaction in the base alloy. The newly formed compounds of additives were restricting the recrystallization and grain growth in subsequent stages.

The scanning electron microscopy (SEM) in Figure 3(a) shows the microstructure of the as-quenched alloy I sample. The dark areas indicate the primary solid solution and the bright areas indicate the non-equilibrium eutectic solid solution between grains. The energy-dispersive X-ray (EDX) scan in Figure 3(b) for the gray particles reveals the chemical composition for the encircle region, in which the elements were similar to the T- $\mathrm{Al}_{5} \mathrm{Mg}_{11} \mathrm{Zn}_{4}, \mathrm{~S}$ -

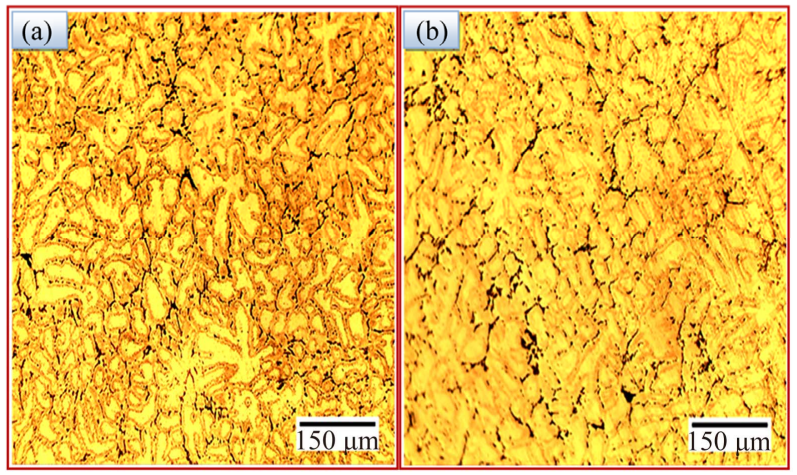

Figure 2. Optical microstructures of alloy I after (a) T6 temper (b) RRA process.

$\mathrm{Al}_{2} \mathrm{CuMg}, \eta-\mathrm{MgZn}_{2}, \eta^{\prime}-\mathrm{Mg}_{2} \mathrm{Zn}_{11}, \gamma-\mathrm{Al}-\mathrm{Cu}-\mathrm{Ni}$, and Al-Ni$\mathrm{Fe}$ phases. These results are consistent with those obtained by Liang [18], who found that aluminium alloys (7xxx) contain the T, S, $\eta$ and $\gamma$ phases with $\mathrm{Al}, \mathrm{Zn}, \mathrm{Mg}, \mathrm{Cu}$ and Ni. The alloy I samples were homogenized under different temperatures conditions and aged at $120^{\circ} \mathrm{C}$ for $24 \mathrm{~h}(\mathrm{~T} 6)$. The SEM micrograph in Figure 4(a) reveals the existence of dispersoid particles (bright spots). The EDX scan in Figure 4(b) for the encircle region also reveals the chemical composition of the bright region. The stoichiometry of this labeled region was close to that of the T$\mathrm{Al}_{5} \mathrm{Mg}_{11} \mathrm{Zn}_{4}, \mathrm{~S}-\mathrm{Al}_{2} \mathrm{CuMg}, \quad \eta-\mathrm{MgZn}_{2}, \quad \eta^{\prime}-\mathrm{Mg}_{2} \mathrm{Zn}_{11}, \quad \gamma-\mathrm{Al}-$ $\mathrm{Cu}-\mathrm{Ni}$, and $\mathrm{Al}-\mathrm{Ni}-\mathrm{Fe}$ phases.

The SEM and EDX scan in Figures 5(a) and (b) show the microstructure of the alloy I sample after RRA process. The SEM reveals the existence of compounds of particle which them details in the EDX scan of the labeled region indicates that these bright spots exhibit stoichiometry close to that of $\mathrm{T}-\mathrm{Al}_{5} \mathrm{Mg}_{11} \mathrm{Zn}_{4}, \mathrm{~S}-\mathrm{Al}_{2} \mathrm{CuMg}, \eta-\mathrm{MgZn}_{2}$, $\eta^{\prime}-\mathrm{Mg}_{2} \mathrm{Zn}_{11}, \gamma-\mathrm{Al}-\mathrm{Cu}-\mathrm{Ni}$, and Al-Ni-Fe compounds (Figure 5(b)).

The XRD analysis results for the alloy I samples are shown in Figures 6(a)-(c) (RRA, T6, and as-quenched, respectively). The patterns of the as-quenched alloy I sample confirm that the primary eutectic system mainly consisted of $\alpha(\mathrm{Al})$, solid solution, and intermetallic compounds (i.e., T- $\mathrm{Al}_{5} \mathrm{Mg}_{11} \mathrm{Zn}_{4}, \mathrm{~S}-\mathrm{Al}_{2} \mathrm{CuMg}, \mathrm{Al}_{7} \mathrm{Cu}_{4} \mathrm{Ni}$, $\mathrm{Al}_{50} \mathrm{Mg}_{48} \mathrm{Ni}_{7}, \mathrm{Al}_{4} \mathrm{Ni}_{3}, \mathrm{Al}_{3} \mathrm{Ni}_{2}$, and $\mathrm{Al}_{75} \mathrm{Ni}_{10} \mathrm{Fe}_{15}$ ). Figure 6(b) shows the XRD plots for the alloy I sample after T6 temper and indicates the existence of the $\mathrm{MgZn}_{2}$ and $\mathrm{Mg}_{2} \mathrm{Zn}_{11}$ phases besides peaked high of the $\mathrm{Al}_{3} \mathrm{Ni}_{2}$ phase. Dispersive phases had many peaks because of the intensive dissolution of the alloying elements and the nickel additives produced by homogenize treatment and subsequent aging at $\mathrm{T} 6$ temper and retrogression and reaging. This result can be explained by the intensive solution treatment of the alloying elements and the addition of nickel. Prior studies indicated to disadvantage for nickel additives into $\mathrm{Al}-\mathrm{Zn}-\mathrm{Mg}-\mathrm{Cu}$ alloys as by $\mathrm{Li}$ et al. [19] 


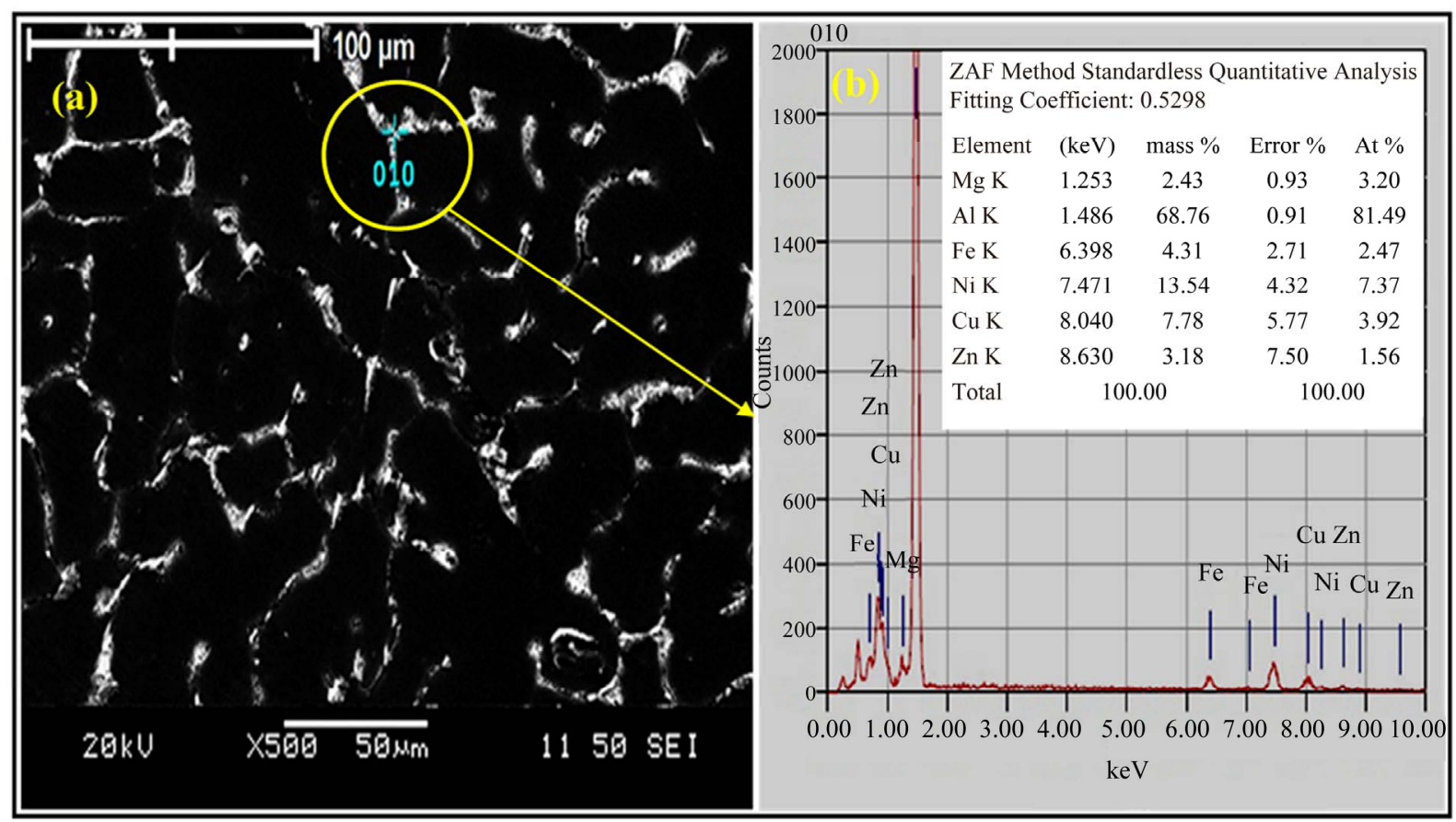

Figure 3. (a) SEM and (b) EDX scan of as-quenched alloy I sample.

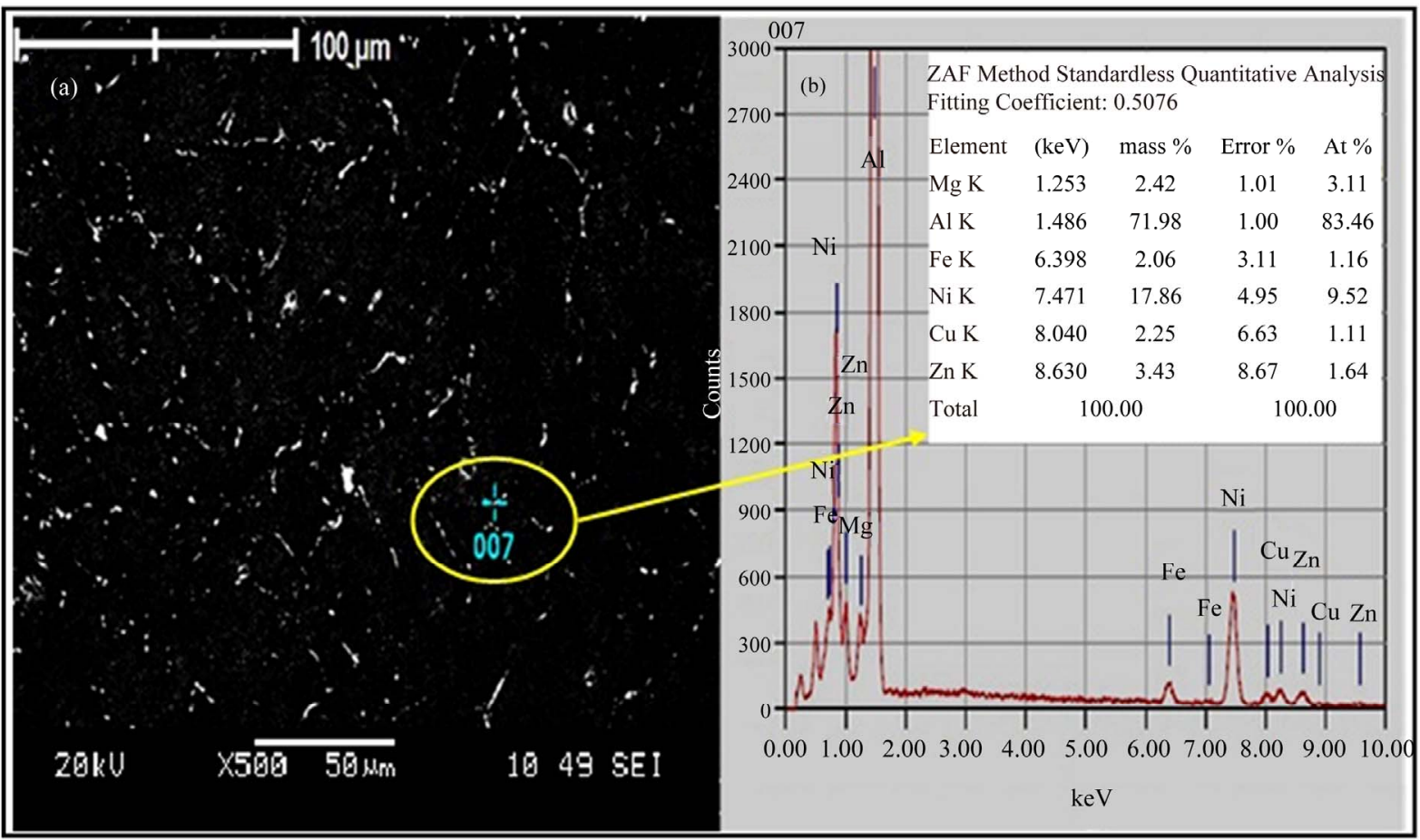

Figure 4. (a) SEM and (b) EDX scan of alloy I sample after T6 temper.

found that adding nickel to aluminum alloys Al-Zn-Mg$\mathrm{Cu}$ suppresses the formation of the $\mathrm{MgZn}_{2}$ phase in the matrix. These findings contradict the present results according to EDX and XRD analysis (i.e., numerous $\mathrm{MgZn}_{2}$ phases). Figure 6(a) shows the XRD plots for the alloy I sample after RRA. The intensity of the diffraction peaks of phase $\mathrm{Al}_{4} \mathrm{Ni}_{3}$ besides $\mathrm{Al}_{75} \mathrm{Ni}_{10} \mathrm{Fe}_{15}$, and $\mathrm{Al}_{3} \mathrm{Ni}_{2}$. There are many peaks of the $\mathrm{MgZn}_{2}$, and $\mathrm{Mg}_{2} \mathrm{Zn}_{11}$ are increased this because of the effects of steps the retrogression and reaging process which its details as follow- 


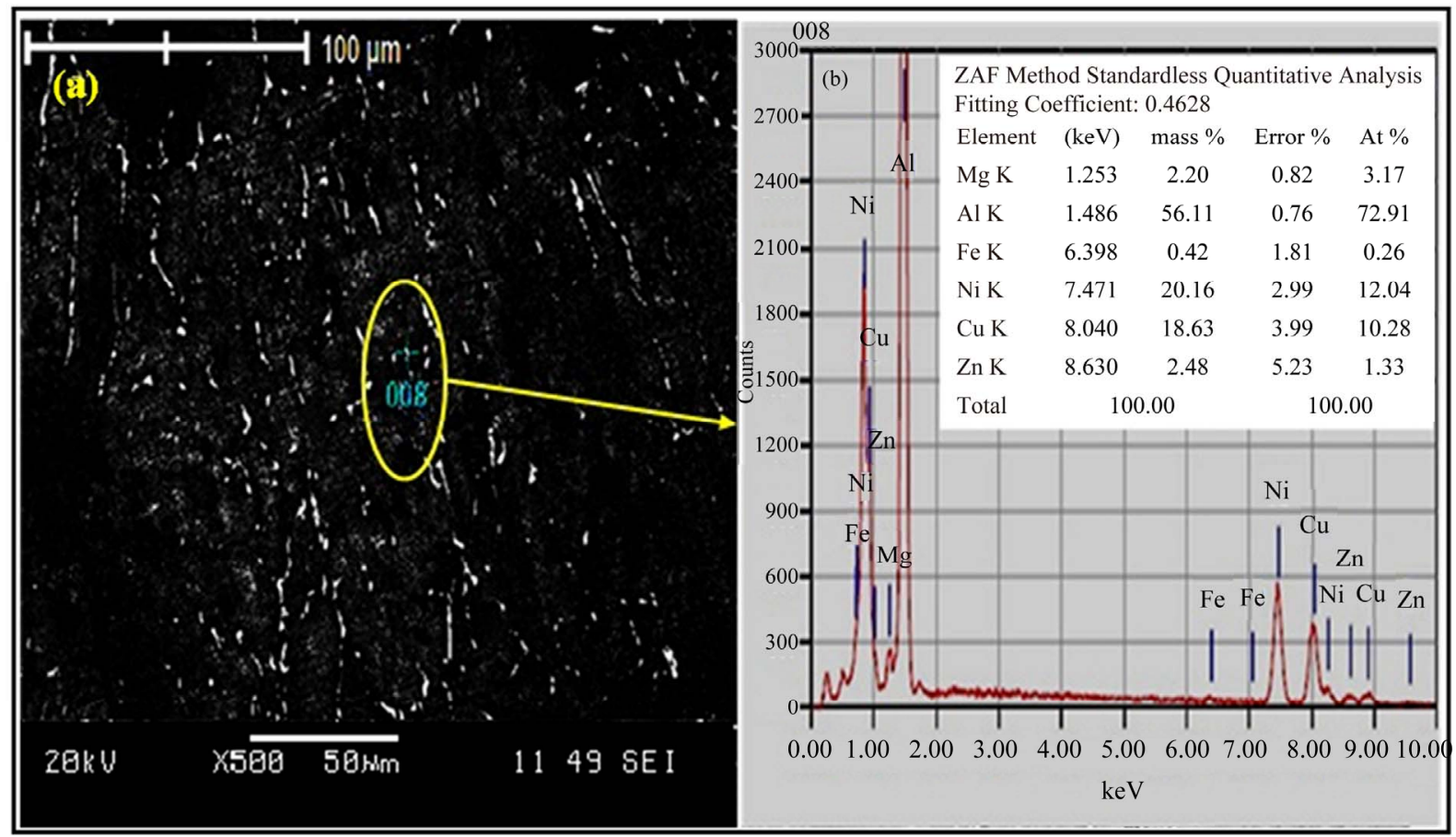

Figure 5. (a) SEM and (b) EDX scan of alloy I sample after RRA heat treatment.

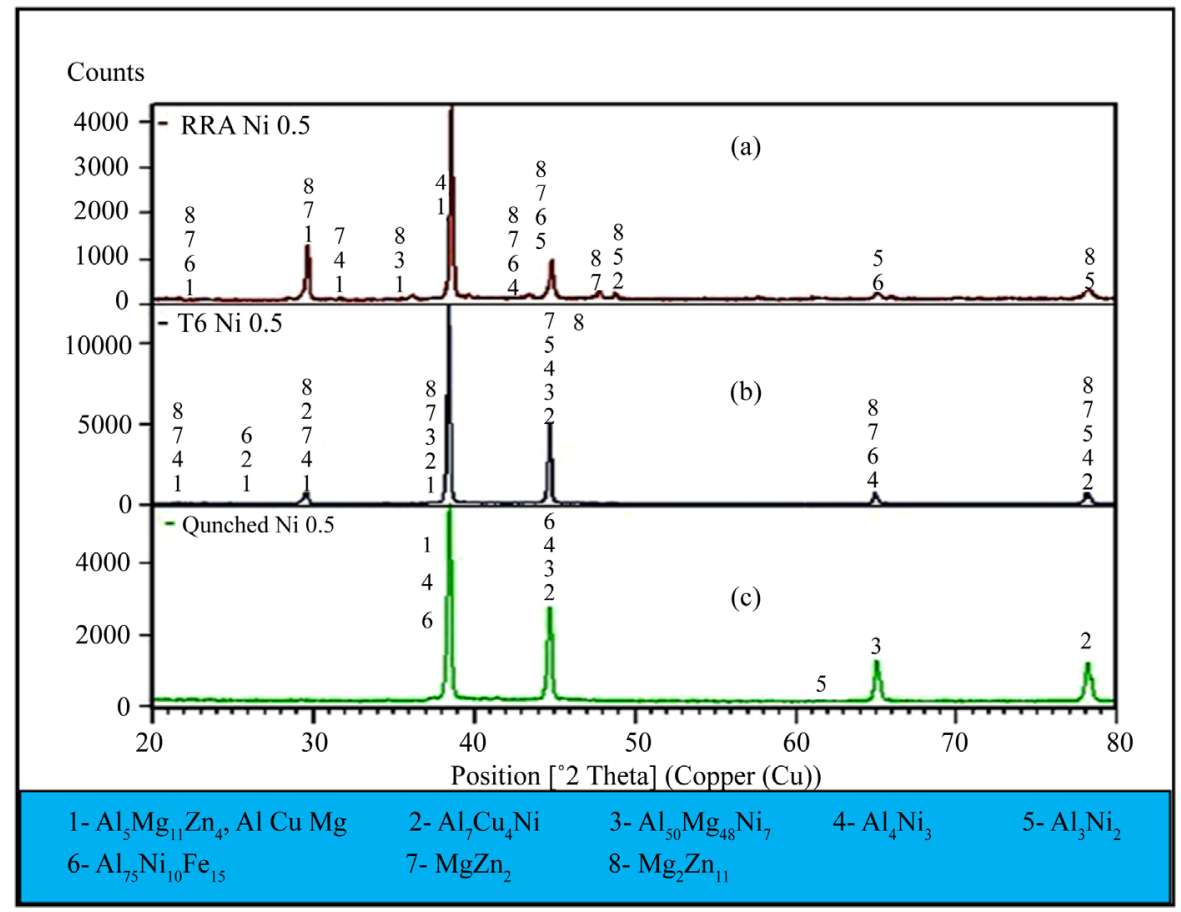

Figure 6. XRD plots for alloy I after as-quenched, T6 heat treatment, and RRA.

ing: The generally accepted precipitation sequences for 7000 series aluminum alloys are as follows: [20,21]; supersaturated solid solution $\rightarrow$ coherent stable GuinierPreston (GP) zones $\rightarrow$ semi-coherent intermediate $\eta^{\prime}$ $\left(\mathrm{Mg}_{2} \mathrm{Zn}_{11}\right)$ phase $\rightarrow$ incoherent stable $\eta\left(\mathrm{MgZn}_{2}\right)$ or $\mathrm{T}$
$\left(\mathrm{AlMg}_{4} \mathrm{Zn}_{11}\right)$ phase. Metastable $\eta^{\prime}$ phase was the primary precipitation hardening phase of these alloys. The primary precipitations in the matrix were the GP zones and $\eta^{\prime}\left(\mathrm{Mg}_{2} \mathrm{Zn}_{11}\right)$ phase after aging at T6. The XRD findings for the samples after T6 and RRA (Figures 6(a) and (b)) 
indicated high-intensity diffraction peaks in the $\mathrm{MgZn}_{2}$ and $\mathrm{Mg}_{2} \mathrm{Zn}_{11}$ phases. The primary precipitation phases in the matrix (the fine and dispersive GP zone and $\eta^{\prime}$ phase) after its step first $\left(120^{\circ} \mathrm{C}\right.$ for $\left.24 \mathrm{~h}\right)$ aging. While with the RRA process and during retrogression period that the un-dissolved GP zones transformed into the $\eta^{\prime}\left(\mathrm{Mg}_{2} \mathrm{Zn}_{11}\right)$ or $\eta\left(\mathrm{MgZn}_{2}\right)$ phase and thus formed numerous GP zones and $\eta^{\prime}$ phases that were dissolved in the early stages of another round of retrogression [22,23]. Finally, abundant nuclei that promote the re-precipitation of the GP zones and $\eta^{\prime}$ phase in the re-aging step were mounted according to the XRD results.

Figure 7 indicates to the strength of alloy I under different conditions. Treating the alloy I with T6 and RRA yielded maximum gains of $200 \mathrm{MPa}$ (T6) and $222 \mathrm{MPa}$ (RRA) in ultimate tensile strength (UTS).

Figure 8 indicates to the variations in the Vickers hardness of the alloy specimens under different conditions.

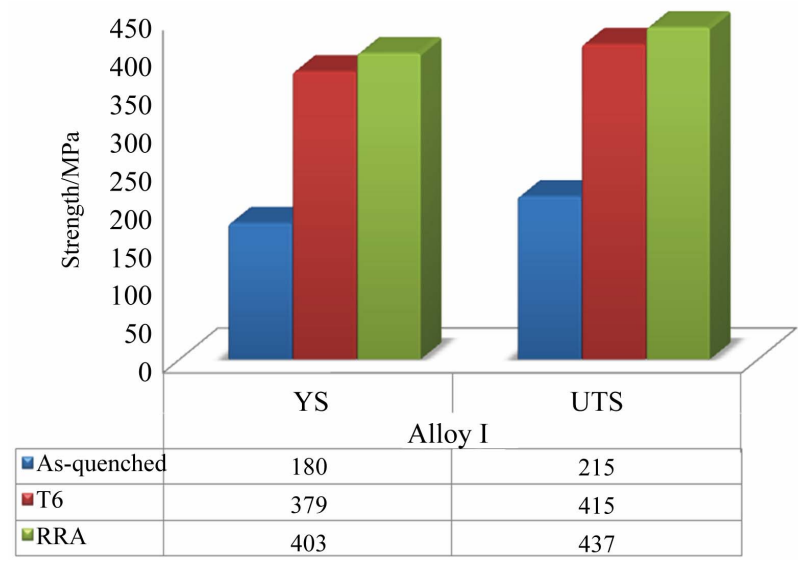

Figure 7. Variations in tensile strength of alloy I specimens before and after different heat treatment conditions.

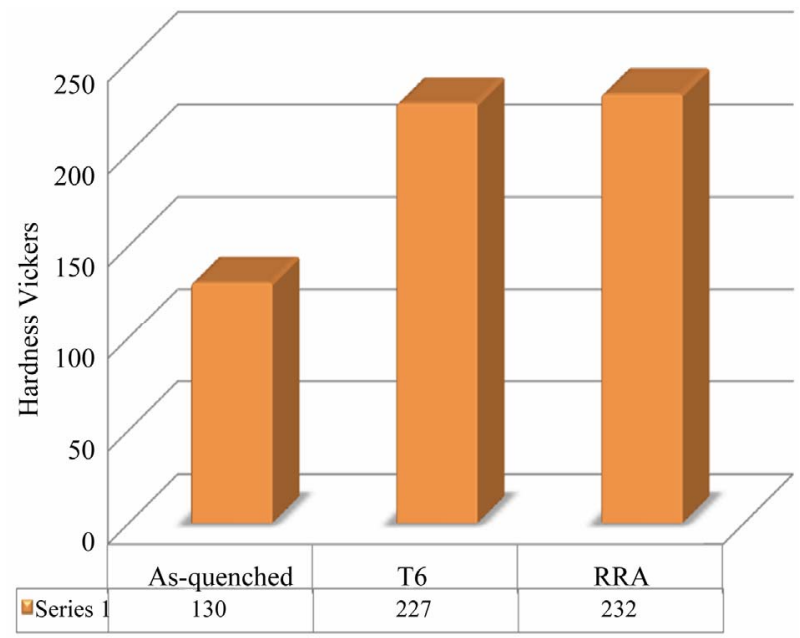

Figure 8. Indicates the variations in the Vickers hardness of the alloy I specimens under different conditions.
Maximum gains of 97 and 102 HV (alloy I) in Vickers hardness were obtained.

\section{Discussion}

The results indicated that the yield strength (YS), ultimate tensile strength (UTS) and Vickers hardness (HV) of alloy I substantially improved after T6 temper and RRA. Enhancement of mechanical properties attribute to two possible strengthening mechanisms to be considered in this study. These mechanisms here are precipitation hardening and dispersion strengthening of additives. The precipitation hardening for the $\mathrm{Al}-\mathrm{Zn}-\mathrm{Mg}-\mathrm{Cu}$ alloy is attributed to influence of aging at $\mathrm{T} 6\left(120^{\circ} \mathrm{C}\right.$ for $\left.24 \mathrm{~h}\right)$ that is the GP zones consistent with the nano-sized $\eta^{\prime}$ metastable of precipitates which are acted as pinning points that impede dislocation [22]. The strength of alloy I sample after RRA significantly improved compared with those of the T6 temper specimens. This improvement is attributed to during retrogression period $\left(180^{\circ} \mathrm{C}\right.$ for $30 \mathrm{~min}$.) the partial dissolution of the pre-existing GP zones can act as nucleation sites for $\eta^{\prime}$ phase. The GP zones and the remaining $\eta^{\prime}$ phase constantly grew during reaging $\left(120^{\circ} \mathrm{C}\right.$ for $\left.24 \mathrm{~h}\right)$. Further, dispersion strengthening can be described that the nickel-rich dispersoids particles are incoherent, dislocations circumvent or bypass them. The relevant process was suggested by Orowan mechanism [24]. The stress causes the dislocation to bow out between the particles. If the stress is sufficiently high, the dislocation has left a loop lead around each particle. These loops lead to high work-hardening rates. The stress required to move a dislocation around a particle is the yield strength.

So the increase in the yield strength (YS) due to the Orowan strengthening, $\Delta \sigma y$, or was given by Equation (1) [25]:

$$
\Delta \sigma \mathrm{y}, \mathrm{Or}=2 \mathrm{~Gb} / \mathrm{Ld}
$$

where, $G$ is the shear modulus of the matrix, $b$ is the Burger's vector of the dislocation; $\mathrm{Ld}$ is the interparticle spacing of the dispersoids.

The application of the T6 temper and the RRA processes on alloy I containing $\mathrm{Ni}$ additives have resulted in lower Ld spacing as compared to the $\mathrm{Ld}$ values of the base alloy phases subjected to the same heat treatments as shown by the in Table 3 . Consequently according to Equation (1), this resulted in higher yield strength for this alloy.

\section{Conclusions}

1) The microstructure of the alloy I contained $\mathrm{Al}_{5} \mathrm{Mg}_{11} \mathrm{Zn}_{4}, \mathrm{Al}_{2} \mathrm{CuMg}, \mathrm{Mg}_{2} \mathrm{Zn}_{11}$, and $\mathrm{MgZn}_{2}$ phases. Adding nickel into the base alloy formed new dispersion 
Table 3. The XRD results for the compounds appearing in the alloy I tested.

\begin{tabular}{ccc}
\hline Type of alloy & Compounds & d-spacing $(\AA)$ \\
\hline \multirow{4}{*}{ Base alloy } & $\mathrm{Al}_{5} \mathrm{Mg}_{11} \mathrm{Zn}_{4}$ & 2.35605 \\
& $\mathrm{AlMg}_{4} \mathrm{Zn}_{11}$ & 2.34829 \\
& $\mathrm{Al}_{2} \mathrm{CuMg}$ & 2.31249 \\
& $\mathrm{Mg}_{2} \mathrm{Zn}_{11}$ & 2.07419 \\
& $\mathrm{MgZn}_{2}$ & 2.16920 \\
& $\mathrm{Al}_{7} \mathrm{Cu}_{4} \mathrm{Ni}$ & 2.04391 \\
& $\mathrm{Al}_{4} \mathrm{Ni}_{3}$ & 2.01674 \\
& $\mathrm{Al}_{75} \mathrm{Ni}_{10} \mathrm{Fe}_{15}$ & 2.05108 \\
& $\mathrm{Al}_{3} \mathrm{Ni}_{2}$ & 2.00637 \\
& $\mathrm{Al}_{50} \mathrm{Mg}_{48} \mathrm{Ni}_{7}$ & 2.49186 \\
\hline
\end{tabular}

particles, such as $\mathrm{Al}_{7} \mathrm{Cu}_{4} \mathrm{Ni}, \mathrm{Al}_{4} \mathrm{Ni}_{3}, \mathrm{Al}_{75} \mathrm{Ni}_{10} \mathrm{Fe}_{15}, \mathrm{AlNi}_{3}$, and $\mathrm{Al}_{50} \mathrm{Mg}_{48} \mathrm{Ni}_{7}$.

2) RRA improved the YS of alloy I more significantly than the T6 temper and significantly increased UTS (i.e., $437 \mathrm{MPa}$ ).

3) The YS of alloy I was increased by the dispersion phase particles $\left(\mathrm{Al}_{7} \mathrm{Cu}_{4} \mathrm{Ni}, \mathrm{Al}_{4} \mathrm{Ni}_{3}, \mathrm{Al}_{75} \mathrm{Ni}_{10} \mathrm{Fe}_{15}, \mathrm{Al}_{3} \mathrm{Ni}_{2}\right.$, and $\mathrm{Al}_{50} \mathrm{Mg}_{48} \mathrm{Ni}_{7}$ ), which restricted the recrystallization and grain growth.

4) The strengthening mechanisms of alloy I which was precipitation hardening related to the alloying elements.

\section{Acknowledgements}

This work is supported under the grant No. 9001-00338 of the University Malaysia Perlis (UniMAP). The authors gratefully acknowledge the outstanding support provided by the technicians of the work shop of Materials Engineering School, UniMAP.

\section{REFERENCES}

[1] N. Pourkia, M. Emamy, H. Farhangi and S. H. Syed Ebrahimi, "The Effect of $\mathrm{Ti}$ and $\mathrm{Zr}$ Elements and Cooling Rate on the Microstructure and Tensile Properties of a New Developed Super High-Strength Aluminum Alloy," Materials Science and Engineering, Vol. 527, No. 20, 2010, pp. 5318-5325.

http://dx.doi.org/10.1016/j.msea.2010.05.009

[2] D. K. N. Birbilis and P. A. Rometsch, "The Effect of PreAgeing Temperature and Retrogression Heating Rate on the Strength and Corrosion Behavior of AA7150," Corrosion Science, Vol. 54, 2012, pp. 17-25. http://dx.doi.org/10.1016/j.corsci.2011.08.042

[3] S. T. Lim, II S. Eun and S. W. Nam, "Control of Equilibrium Phases $(\mathrm{M}, \mathrm{T}, \mathrm{S})$ in the Modified Aluminum Alloy 7175 for Thick Forging Applications," Materials Transactions, Vol. 44, No. 1, 2003, pp. 181-187.

[4] A. K. Mukhopadhyay, "Microstructure and Properties of
High Strength Aluminum Alloys," Transactions of the Indian Institute of Metals, Vol. 62, No. 2, 2009, pp. 113122. http://dx.doi.org/10.1007/s12666-009-0015-Z

[5] B. C. Wei, C. Q. Chen and Y. G. Zhang, "Aging Behavior of Li Containing Al-Zn-Mg-Cu Alloys," Materials Science and Engineering A, Vol. 280, No. 1, 2000, pp. 161167. http://dx.doi.org/10.1016/S0921-5093(99)00684-X

[6] Y. Deng, Z. M. Yin, K. Zhao, J. Q. Duan, J. Hu and Z. B. $\mathrm{He}$, "Effects of Sc and $\mathrm{Zr}$ Microalloying Additions and Aging Time at $120^{\circ} \mathrm{C}$ on the Corrosion Behaviour of an Al-Zn-Mg Alloy," Corrosion Science, Vol. 65, 2012, pp. 288-298.

[7] D. N. Compton, L. A. Cornish and M. J. Witcomp, "The Effect of Microstructure on Hardness Measurements in the Aluminum-Rich Corner of the Al-Ni-Cr System," Journal of Alloys and Compounds, Vol. 317-318, 2001, pp. 372-378.

http://dx.doi.org/10.1016/S0925-8388(00)01441-9

[8] Y. Yang, K. L. Yu, Y. G. Li, D. G. Zhao and X. F. Liu, "Evolution of Nickel-Rich Phases in Al-Si-Cu-Ni-Mg Piston Alloys with Different $\mathrm{Cu}$ Additions," Materials \& Design, Vol. 33, 2012, pp. 220-225. http://dx.doi.org/10.1016/j.matdes.2011.06.058

[9] U. Boyuk, S. Engin and N. Marasli, "Microstructural Characterization of Unidirectional Solidified Eutectic Al-SiNi Alloy," Materials Characterization, Vol. 62, 2011, pp. 844-851. http://dx.doi.org/10.1016/j.matchar.2011.05.010

[10] N. A. Belov, D. G. Eskin and N. N. Avxentieva, "Constituent Phase Diagrams of the Al-Cu-Fe-Mg-Ni-Si System and Their Application to the Analysis of Aluminum Piston alloys," Acta Materialia, Vol. 53, 2005, pp. 47094722. http://dx.doi.org/10.1016/j.actamat.2005.07.003

[11] Y. Yang, Y. Li, W. Wu, D. Zhao and X. Liu, "Effect of Existing Form of Alloying Elements on the Microhardness of Al-Si-Cu-Ni-Mg Piston Alloy," Materials Science and Engineering: A, Vol. 528, No. 18, 2011, pp. 57235728. http://dx.doi.org/10.1016/j.msea.2011.04.022

[12] H. A. Ammar, C. Moreau, A. M. Samuel, F. H. Samuel and H. W. Doty, "Influences of Alloying Elements, Solution Treatment Time and Quenching Media on Quality Indices of 413-Type Al-Si Casting Alloys," Materials Science and Engineering: A, Vol. 489, No. 1-2, 2008, pp. 426-438. http://dx.doi.org/10.1016/j.msea.2007.12.032

[13] J. Shen, R. Liu, Y. Liu, Z. Jiang and Q. Li, "Microstructures and Tensile Properties of Spray-Deposited HighStrength Aluminum Alloys," Journal of Materials Science, Vol. 32, No. 3, 1997, pp. 829-832. http://dx.doi.org/10.1023/A:1018533112503

[14] W.-B. Li, Q.-L. Pan, Y.-P. Xiao, Y.-B. He and X.-Y. Liu, "Microstructure Evolution of Ultra-High Strength Al-Zn$\mathrm{Cu}-\mathrm{Mg}-\mathrm{Zr}$ Alloy Containing Sc during Homogenization," Transactions of Nonferrous Metals Society of China, Vol. 21, No. 10, 2011, pp. 2127-2133. http://dx.doi.org/10.1016/S1003-6326(11)60984-9

[15] G.-S. Peng, K.-H. Chen, S.-Y. Chen and H.-C. Fang, "Influnce of Dual Retrogression and Re-Aging Temper on Microstructure, Strength and Exfoliation Corrosion Behavior of Al-Zn-Mg-Cu Alloy," Transactions of Nonfer- 
rous Metals Society of China, Vol. 22, No. 4, 2012, pp. 803-809. http://dx.doi.org/10.1016/S1003-6326(11)61248-X

[16] H. T. Naeem, K. S. Mohammed, K. R. Ahmad and A. Rahmat, "The Role of Direct Chilling, Retrogression and Reaging Treatment on Mechanical Properties of High Strength Aluminum Alloy," Advance Materials Research, Vol. 795, 2013, pp. 211-218.

[17] O. P. Gbenebor, M. Abdulwahab and O. S. I. Fayomi, "Influnce of Inoculant Addition and Cooling Medium on the Mechanical Properties of Aa6063-Type Al-Mg-Si Alloy," Chalcogenide Letters, Vol. 16, 2011.

[18] Z.-L. Li, J.-X. Xie, W. Chen, J. Zhai, H.-P. Ren and Y.-F. Wang, "Effects of Soild-Solution on Microstructure and Property of High Strength Spray Deposited Al-Zn-Mg-Cu Alloy Modified By Ni," The Chinese Journal of Nonferrous Metals, Vol. 19, No. 12, 2009, pp. 2099-2105.

[19] L. Li, T.-T. Zhou, H.-X. Li, C.-Q. Chen, B.-Q. Xiong and L.-K. Shi, "Effect of Additional Elements on Aging Behavior of Al-Zn-Mg-Cu Alloys by Spray Forming," Transactions of Nonferrous Metals Society of China, Vol. 16, No. 3, 2006, pp. 532-538. http://dx.doi.org/10.1016/S1003-6326(06)60093-9

[20] G.-F. Li, X.-M. Zhang, P.-H. Li and J.-H. You, "Effects of Retrogression Heating Rate on Microstructures and
Mechanical Properties of Aluminum Alloy 7050," Transactions of Nonferrous Metals Society of China, Vol. 20, No. 6, 2010, pp. 935-941. http://dx.doi.org/10.1016/S1003-6326(09)60239-9

[21] R. J. Flynn and J. S. Robinson, "The Application of Advances in Quench Factor Analysis Property Prediction to the Heat Treatment of 7010 Aluminum Alloy," Journal of Materials Processing Technology, Vol. 153-154, 2004, pp. 674-680. http://dx.doi.org/10.1016/j.jmatprotec.2004.04.133

[22] I. J. Polmear, "Light Alloys from Traditional Alloys to Nanocrystals," Elsevier, Australia, 2006.

[23] W. H. Yuan, J. Zhang, C. C. Zhang and Z. H. Chen, "Processing of Ultra-High Strength $\mathrm{SiCp} / \mathrm{Al}-\mathrm{Zn}-\mathrm{Mg}-\mathrm{Cu}$ Composites," Journal of Materials Processing Technology, Vol. 209, No. 7, 2009, pp. 3251-3255. http://dx.doi.org/10.1016/j.jmatprotec.2008.07.030

[24] E. Nembach, "Particle Strenghtening of Metals and Alloys," John Wily \& Sons, Inc., 1997.

[25] M. M. Sharma, M. F. Amateua and T. J. Eden, "Hardening Mechanisms of Spray Formed Al-Zn-Mg-Cu Alloys with Scandium and Other Elemental Additions," Journal of Alloys and Compounds, Vol. 416, No. 1-2, 2006, pp. 135-142. http://dx.doi.org/10.1016/j.jallcom.2005.08.045 